\title{
EVALUASI PELAKSANAAN KEBIJAKAN SANTUNAN KEMATIAN BERDASARKAN PERWAKO PADANG NOMOR 12 TAHUN 2015
}

\author{
Rezi Pebratama \\ IlmuAdministrasiPublik, FakultasIlmuSosial, UniversitasNegeri Padang \\ rezipebratama@student.unp.ac.id \\ M. Fachri Adnan \\ IlmuAdministrasiPublik, FakultasIlmuSosial, UniversitasNegeri Padang \\ fachriadnan@fis.unp.ac.id \\ Adil Mubarak \\ IlmuAdministrasiPublik, FakultasIlmuSosial, UniversitasNegeri Padang \\ adilmubarak@yahoo.co.id
}

\begin{abstract}
This study aimed to evaluate the implementation of the life insurance policy in Padang City. This study is based on a number of problems, namely that there were still many poor people in Padang City did not know the implementation of the Life Insurance Policy. There were still many poor people in Padang City did not have a Community Health Insurance Card or Regional Health Insurance as one of the conditions for obtaining the life insurance funds. This study was a descriptive with qualitative approach. The informants in this study were determined through purposive technique. Data were collected through observation, interview and documention studies. The results of this study indicated that the implementation of the life insurance policy has not been effective, based onpolicy evaluation indicators used by William Dunn, that is the maximization in goal achievement, efficiency in implementation effort, community satisfaction for government policy, equal distribution. The life insurancefunds has been distributed evenly, the community supported the life insurance policy, and the life insurance policy is right to be implemented among community in Padang City.
\end{abstract}

Keywords:Policy, evaluation, life insurance, poor people

How to Cite: Rezi Pebratama, M. Fachri Adnan dan Adil Mubarak. 2019. Evaluasi Pelaksanaan Kebijakan Santunan Kematian berdasarkan Perwako Padang Nomor 12 Tahun 2015. 3(2): pp.156-166. DOI: https://doi.org/10.24036/jess/vol3-iss2 


\section{Pendahuluan}

Menurut Undang-Undang Nomor 36 Tahun 2009 Tentang Kesehatan pada Pasal 117, seseorang dinyatakan mati apabila fungsi sistem jantung sirkulasi dan sistem pernafasan terbukti telah berhenti secara permanen. Dalam Al-Qur'an surah Yunus ayat 49 menyatakan tentang kematian yaitu :

“... Tiap-tiap umat mempunyai ajal. Apabila telah datang ajal mereka, maka mereka tidak dapat mengundurkannya barang sesaatpun dan tidak (pula) mendahulukan (nya)."

Manusia mati meninggalkan duka meskipun kematian adalah sebuah kepastian, tutup usia seseorang tidak dapat dipastikan waktunya. Bila manusia mati ia meninggalkan risiko bagi orang lain, yaitu adanya beban biaya kematian yang harus ditanggung oleh keluarga.Banyak kita temui masyarakat di Kota Padang yang tidak mampu mengurusi penyelenggaraan kematian keluarganya karena keterbatasan ekonomi.

Sementara itu, untuk mengurangi beban biaya kematian yang ditanggung oleh keluarga yang ditinggalkan, Pemerintah Kota Padang mengeluarkan Peraturan Walikota Padang nomor 25 tahun 2014 tentang Santunan Kematian. Sumber dana untuk program santunan kematian adalah dari Anggaran Pendapatan dan Belanja Daerah Kota Padang yang berpedoman pada Peraturan Menteri Dalam Negeri Nomor 32 Tahun 2011 Tentang Pedoman Pemberian Hibah dan Bantuan Sosial. Tidak lama kemudian Peraturan Walikota Padang nomor 25 tahun 2014 tentang santunan kematian tersebut dirubah menjadi Peraturan Walikota Padang nomor 29. A tahun 2014 tentang santunan kematian, karena ditemukan oleh pihak BPK yaitu penyalahgunaan dalam penggunaan dana bantuan sosial. Dimana yang berhak mendapatkan santunan kematian harus memenuhi persyaratan yang tertulis pada Pasal 7 yaitu a) Surat permohonan ahli waris; b) KK dan KTP yang meninggal; c) KK dan KTP keluarga/ahli waris; d) Surat keterangan kematian dari Lurah; dan Surat keterangan miskin / tidak mampu dari Lurah.

Pelaksanaan Peraturan Walikota Padang tentang santunan kematian sempat berhenti beberapa bulan dan berjalan lagi pada tanggal 21 Mei 2015. Peraturan Walikota tentang santunan kematian dirubah lagi menjadi Peraturan Walikota Padang Nomor 12 tahun 2015 tentang Santunan Kematian karena ditemukan oleh pihak BPK yaitu masih menyalahgunakan dalam penggunaan dana bantuan sosial. Dana untuk kepastian hukum masyarakat yang akan menerima santunan kematian benar-benar masyarakat miskin. Setiap masyarakat miskin dapat mengurus dana santunan kematian dengan syarat memenuhi ketentuan persyaratan berdasarkan Pasal 4 pada Peraturan Walikota Padang Nomor 12 Tahun 2015 Tentang Santunan Kematian yaitu : a) Masyarakat miskin yang terdaftar dalam pendataan Program Perlindungan Sosial 2011, Jaminan Kesehatan Masyarakat atau Jaminan Kesehatan Daerah; b) meninggal dunia di Kota Padang; c) memiliki KK dan atau KTP Kota Padang; d) melaporkan kematian paling lama 30 (tiga puluh) hari sejak tanggal kematian; e) memiliki Surat Keterangan Kematian dari dokter, rumah 
sakit atau pejabat yang berwenang; f) memiliki Surat Keterangan Kematian dari lurah setempat. Tujuan dari kebijakan santunan kematian adalah untuk meringankan beban ahli waris atau family penduduk Kota Padang yang meninggal dunia dalam menyelenggarakan pemakaman.

Namun dalam kenyataanya, semenjak peraturan tentang santunan kematian ini dikeluarkan dan semenjak pelaksanaan peraturan tentang santunan kematian berhenti beberapa bulan pada tahun 2015, pelaksanaan kebijakan santunan kematian berjalan kurang efektif, karena masih banyak kelurahan yang tidak mengetahui bahwasanya peraturan tentang santunan kematian ini dilaksanakan kembali, banyak masyarakat Kota Padang yang belum mengetahui pelaksanaan kebijakan santunan kematian dan banyak masyarakat miskin di Kota Padang yang belum memiliki Kartu Jaminan Kesehatan masyarakat atau Jaminan Kesehatan Daerah sebagai salah satu syarat untuk mendapatkan dana santunan kematian.

Berasarkan latar belakang masalah diatas, maka penulis telah melakukan penelitian pada Bagian Kesra Kota Padang tentang evaluasi pelaksanaan kebijakan santunan kematian di Kota Padang Sumatera Barat. Rumusan masalah yang diangkat dalam penelitian ini adalah bagaimana evaluasi pelaksanaan Kebijakan Peraturan Walikota Padang tentang santunan kematian?

\section{Tinjauan Kepustakaan}

\section{Kebijakan Publik}

Teori dan proses kebijakan publik tidak hanya menekankan pada hal-hal yang diusulkan pemerintah, tetapi juga mencakup arah tindakan yang dilakukan pemerintah. Anggara (2018) menjelaskan sifat kebijakan publik sebagai arah tindakan dapat dipahami secara lebih baik apabila konsep ini diperinci menjadi beberapa kategori- kategori, diantaranya tuntutan kebijakan, keputusan kebijakan, pernyataan kebijakan, hasil kebijakan, dan dampak kebijakan.

Menurut Easton (1969) kebijakan publik sebagai "The authoritative allocation of values for the whole society". Berdasarkan pendapat diatas, Eatson menegaskan pilihan pemerintah untuk melakukan atau tidak melakukan sesuatu harus diwujudkan dalam pengalokasian nilai-nilai kepada masyarakat. Kemudian Dunn (2000) menjelaskan terdapat beberapa proses dalam pembuatan kebijakan publik diantaranya agenda setting, policy formulation, policy adoption, policy implementation, dan policy evaluation.

Berdasarkan penjelasan pengertian kebijakan publik menurut para ahli diatas dapat disimpulkan bahwa kebijakan publik merupakan tindakan yang sah dilaksanakan atau tidak dilaksanakan oleh pemerintah yang melihat pada tujuan kebijakan untuk menyelesaikan masalah publik. Suatu masalah akan menjadi masalah publik jika melibatkan banyak orang dan mempunyai akibat tidak hanya pada orang-orang yang secara langsung terlibat, tetapi juga sekelompok orang yang secara tidak langsung terlibat. 


\section{Evaluasi Kebijakan}

Evaluasi atau penilaian kebijakan menyangkut pembahasan kembali terhadap implementasi kebijakan. Tahap ini berfokus pada identifikasi hasil-hasil dan akibat-akibat dari implementasi kebijakan. Dengan focus tersebut, evaluasi kebijakan akan menyediakan umpan balik bagi penentuan keputusan mengenai apakah kebijakan yang ada perlu diteruskan atau dihentikan. Nugroho (2009) menjelaskan kebijakan publik harus diawasi dan salah satu mekanisme pengawasan tersebut evaluasi kebijakan.

Mulyadi (2015) mengatakan evaluasi kebijakan dibagi tiga yaitu sebelum dilaksanakan, pada waktu dilaksanakan, dan setelah dilaksanakan. Dunn (2000) mengemukakan bahwa evaluasi memiliki fungsi penting antara lain :

1. Evaluasi memberikan informasi yang valid dan dapat dipercaya mengenai kinerja kebijakan.

2. Evaluasi memberi sumbangan terhadap klarifikasi dan kritik terhadap nilainilai yang mendasari pemilihan dan target dalam kebijakan publik.

3. Evaluasi memberi sumbangan pada aplikasi metode-metode analisis kebijakan lainnya, termasuk dalam perumusan masalah maupun rekomendasi pemecahan masalah.

Sedangkan menurut Mulyadi (2015) fungsi dari evaluasi kebijakan ada 6 (enam) sebagai berikut :

1. Menentukan tingkat kinerja suatu kebijakan.

2. Mengukur tingkat efisiensi suatu kebijakan.

3. Mengukur tingkat keluaran suatu kebijakan.

4. Mengukur dampak suatu kebijakan.

5. Untuk mengetahui apabila ada penyimpangan.

6. Sebagai bahan masukan untuk kebijakan.

Menurut Dunn (2000) terdapat 6 (enam) kriteria yang dapat digunakan untuk menilai sebuah kinerja berhasil atau tidak berhasil, yaitu :

1) Efektivitas

Efektivitas selalu terkait dengan hubungan antara hasil yang diharapkan dengan hasil yang sesungguhnya dicapai. Berdasarkan pendapat di atas, bahwa apabila pencapaian tujuan-tujuan dari pada organisasi semangkin besar, maka semangkin besar pula efektivitasnya.

2) Efisiensi

Efisiensi (efficiency) berkenaan dengan jumlah usaha yang diperlukan untuk menghasilkan tingkat efektivitas tertentu. Efisiensi yang merupakan sinonim dari rasionalitas ekonomi, adalah merupakan hubungan antara efektivitas dan usaha, yang terakhir umumnya diukur dari ongkos moneter.

3) Kecukupan

Kecukupan (adequacy) berkenaan dengan seberapa jauh suatu tingkat efektivitas memuaskan kebutuhan, nilai atau kesempatan yang menumbuhkan adanya masalah kecukupan masih berhubungan dengan efektivitas dengan mengukur atau memprediksi seberapa jauh aternatif yang ada dapat memuaskan kebutuhan, nilai atau kesempatan dalam menyelesaikan masalah yang terjadi. 
4) Pemerataan

Pemerataan dalam kebijakan publik dapat dikatakan mempunyai arti dengan keadilan yang diberikan dan diperoleh sasaran kebijakan publik.

5) Responsivitas

Keberhasilan kebijakan dapat dilihat melalui tanggapan masyarakat yang menanggapi pelaksanaan setelah terebih dahulu memprediksi pengaruh yang akan terjadi jika kebijakan akan dilaksanakan, juga tanggapan masyarakat setelah dampak kebijakan sudah mulai dapat dirasakan dalam bentuk dukungan/penolakan.

6) Ketepatan

Ketepatan merujuk pada nilai atau harga dari tujuan program dan pada kuatnya asumsi yang melandasi tujuan-tujuan tersebut. kriteria yang dipakai untuk menseleksi sejumlah alternatif untuk dijadikan rekomendasi dengan menilai apakah hasil dari alternatif yang direkomendasikan tersebut merupakan pilihan tujuan yang layak.

Berdasarkan penejelasan para ahli diatas mengenai evaluasi kebijakan dapat disimpulkan bahwa evaluasi kebijakan merupakan penilaian terhadap program atau kebijakan untuk mengetahui sejauh mana keefektifan suatu kebijakan untuk dipertanggungjawabkan kepada konstituennya. Kemudian untuk mengevaluasi kebijakan dapat dilakukan dengan menggunakan beberapa kriteria yaitu efektivitas, efisiensi, kecukupan, pemerataan, responsivitas, dan ketepatan suatu kebijakan.

\section{Metode Penelitian}

Penelitian menggunakan pendekatan kualitatif. Fokus penelitian yaitu Evaluasi Pelaksanaan Kebijakan Santunan Kematian di Kota Padang Sumatera Barat. Penelitian dilakukan di Bagian Kesejahteraan Rakyat Kota Padang, Badan Pengelolaan Keuangan dan Aset Daerah Kota Padang, Pemerintah Kecamatan Kuranji, Pemerintah Kecamatan Bungus Timur, Pemerintah Kelurahan Kuranji, Pemerintah Kelurahan Bungus Timur, Pengamat Sosial, Pers Singgalang, Politisi, Toko Masyarakat, serta masyarakat sasaran kebijakan santunan kematian.

Teknik pengumpulan data dalam penelitian adalah teknik observasi, teknik wawancara, dan teknik studi dokumentasi. Alat yang digunakan untuk pengumpulan data adalah alat perekam (tape recorder) dan Kamera. Teknik analisis data yang digunakan adalah reduksi data, penyajian data, dan penarikan kesimpulan.

\section{Hasil Penelitian dan Pembahasan}

Untuk mengevaluasi pelaksanaan Peraturan Walikota Padang Nomor 12 Tahun 2015 Tentang Santunan Kematian menggunakan indikator evaluasi yang dikemukakan oleh William Dunn. Menurut Dunn (2000) terdapat 6 (enam) kriteria yang dapat digunakan untuk menilai sebuah kebijakan berhasil atau tidak berhasil, yaitu :

Untuk mengevaluasi Peraturan Walikota Padang nomor 12 tahun 2015 tentang santunan kematian dapat menggunakan indikator evaluasi yang 
dikemukakan oleh William Dunn. Menurut Dunn (2000) terdapat 6 (enam) kriteria yang dapat digunakan untuk menilai sebuah kebijakan berhasil atau tidak berhasil, yaitu :

\section{Pertama efektivitas}

Hasil wawancara dengan Bapak Efendi selaku wartawan Pers Singgalang pada tanggal 04 Mei 2018 dijelaskan bahwa masih banyak masyarakat Kota Padang yang belum mengetahui tentang kebijakan santunan kematian dan masih banyak masyarakat miskin yang belum memiliki Kartu Jamkesmas atau sejenisnya.

Selanjutnya wawancara dengan Bapak Martias Ali selaku Lurah di Kelurahan Kuranji pada tanggal 08 Mei 2018 dijelaskan bahwa pada perubahan Peraturan Walikota Padang tentang santunan kematian yang kedua Kelurahan Kuranji belum mendapatkan informasi dari pemerintah kecamatan dan Kelurahan Kuranji belum menyosialisasikan program ini kepada RT/RW ataupun kepada masyarakat sehingga masih banyak masyarakat yang belum mengetahui program santunan kematian. Kemudian Bapak Jamaris selaku Lurah di Kelurahan Bungus Timur pada tanggal 09 Mei 2018 dijelaskan bahwa Kelurahan Bungus Timur tidak dapat informasi dari Pemerintah Kecamatan mengenai Peraturan Walikota Padang nomor 12 tahun 2015 tentang perubahan kedua atas Peraturan Walikota Padang nomor 25 tahun 2014 tentang santunan kematian dan masyarakat Kelurahan Bungus Timur banyak yang tidak mengetahui peraturan santunan kematian.

Selanjutnya wawancara dengan Ibu Erni selaku masyarakat Kelurahan Kuranji pada tanggal 10 Mei 2018 dijelaskan bahwa ia tidak mengetahui Peraturan Walikota Padang tentang santunan kematian dan belum ada sosialisasi dari Pemerintahkepada masyarakat. Sementara itu Ibu Ermidawati selaku RT 04 Kandang Gabuo Kelurahan Kuranji pada tanggal 10 Mei 2018menjelaskan bahwa masyarakat sangat minim atas informasi mengenai santunan kematian dan masyarakat miskin di RT 04 Kandang Gabuo masih banyak yang belum memiliki kartu BPJS atau sejenisnya yang dibiayai oleh Pemerintah.

Hasil Penelitian dengan Bapak Hendri Satriawan pada 07 Mei 2018 selaku Kasubag Bina Kesra Kota Padang menjelaskan bahwa sumber dana program santunan kematian adalah dari APBD Kota Padang, anggaran untuk tahun 2018 kurang lebih dari Rp. 1 Milyar, tetapi tidak khusus untuk santunan kematian karena Rp. 1 Milyar adalah dana untuk bantuan sosial dan dimasukkan kejenis anggaran dana yang tidak direncanakan, jadi didalamnya termasuk bencana angin puting beliung, kebakaran, banjir dan yang jelas musibah yang tidak direncanakan. Sumber daya finansial dalam pelaksanaan program santunan kematian cukup memadai tetapi belum ada dana untuk menyosialisasikan langsung kepada masyarakat terkait program santunan kematian. Daftar jumlah permohonan bantuan santunan kematian masyarakat Kota Padang dapat dilihat pada table 1 di bawah ini: 
Tabel 1. Daftar Jumlah Permohonan Bantuan Santunan Kematian Masyarakat Kota Padang Tahun 2014 s/d Tahun 2018 Mei

\begin{tabular}{ccccc}
\hline No & $\begin{array}{c}\text { Jumlah } \\
\text { Pemohon }\end{array}$ & Tahun & Jumlah Biaya & $\begin{array}{c}\text { Total Biaya ABPD Kota } \\
\text { Padang Keluar Untuk } \\
\text { Santunan Kematian }\end{array}$ \\
\hline 1 & 540 & 2014 & 1000.000 & 540.000 .000 .00 \\
\hline 2 & 93 & 2015 & 1000.000 & 93.000 .000 .00 \\
\hline 3 & 165 & 2016 & 1000.000 & 165.000 .000 .00 \\
\hline 4 & 170 & 2017 & 1000.000 & 170.000 .000 .00 \\
\hline 5 & 53 (Mei) & 2018 & 1000.000 & 53.000 .000 .00 \\
\hline Sumber : Bagian Kesra Kota Padang & & \\
\hline
\end{tabular}

Hasil penelitian peneliti pada indikator efektivitas yang dijelaskan oleh Dunn dapat disimpulkan bahwa pelaksanaan kebijakan santunan kematian belum efektif, karena kurangnya sosialisasi pemerintah kepada kelompok sasaran sehingga masih banyak masyarakat sasaran yang tidak mengetahui tentang kebijakan santunan kematian dan masih banyak masyarakat miskin yang belum memiliki Kartu Jaminan Kesehatan masyarakat atau Jaminan Kesehatan Daerah sebagai salah satu syarat untuk mendapatkan dana santunan kematian.

Berdasarkan hasil penelitian Fadhli (2014) tentang Evaluasi Program Kelompok Masyarakat yaitu kurang efektifnya pelaksanaan program hibah POKMAS dikarenakan oleh rendahnya kemampuan implementor dalam memenuhi ketentuan implementas program yang tepat sasaran, tepat waktu, tepat jumlah dan tepat mutu. Menurut Dunn (2000) efektivitas selalu berkaitan antara hasil yangdiharapkan dengan hasil yang sesungguhnya dicapai. Untuk mengukur sebuah kebijakan berhasil atau tidak dapat dilakukan dengan cara wawancara dengan kelompok sasaran. Jika kelompok sasaran mengetahui kebijakan yang dilakukan oleh pemerintah, maka dapat dikatakan kebijakan itu berhasil di laksanakan, tetapi jika kelompok sasaran banyak yang tidak mengetahui kebijakan yang dilakukan pemerintah maka sebuah kebijakan gagal untuk dilaksanakan.

\section{Kedua efisiensi}

Hasil wawancara pada tanggal 07 Mei 2018 dengan Bapak Hendri Satriawan, S. Sos selaku Kasubag Bina Kesra Kota Padang dijelaskan bahwa Pemerintah Kota Padang sudah memberi informasi semacam surat tertulis melalui Pemerintah Kecamatan yang ditandatangani oleh Sekretaris Daerah, Pemerintah Kecamatan menyosialisasikan kepada Pemerintah Kelurahan, Pemerintah Kelurahan menyosialisasikan kepada RT/RW yang ada dimasing-masing Kelurahan dan RT/RW menginformasikan kepada Masyarakat.

Berdasarkan hasil wawancara pada 11 Mei 2018 dengan Ibu Rini Yuwira selaku Kasi Kesos-PB Kecamatan Kuranji dan pendapat senada yang peneliti temukan saat wawancara dengan Ibu Rostiati selaku Kasi Kesos-PB Kecamatan Bungus Teluk Kabung menjelaskan bahwa Pemerintah Kota Padang sudah menginformasikan Peraturan Walikota Padang tentang santunan kematian dan 
Pemerintah Kecamatan juga sudah menginformasikan kepada seluruh Kelurahan yang ada di Kecamatan.

Selanjutnya hasil wawancara pada 08 Mei 2018 dengan Bapak Martias Ali selaku Lurah Kuranji dan pendapat senada yang peneliti temukan saat wawancara pada 09 Mei 2018 dengan Bapak Jamaris Yunus selaku Lurah Kelurahan Bungus Timur, menjelaskan belum ada dapat informasi dari Pemerintah Kecamatan mengenai Peraturan Walikota Padang nomor 12 tahun 2015 tentang kebijakan santunan kematian, Kelurahan belum memberikan informasi terkait kebijakan santunan kematian kepada RT/RW, sehingga informasi kebijakan santunan kematian belum tersampaikan kepada masyarakat sasaran.

Hasil penelitian dapat disimpulkan bahwa usaha Pemerintah dalam mengoptimalkan pelaksanaan Peraturan Walikota Padang tentang santunan kematian belum efisien, karena Kelurahan belum mendapatkan informasi terkait dana santunan kematian dan Kelurahan belum memberikan informasi terkait kebijakan santunan kematian kepada RT/RW, sehingga informasi kebijakan santunan kematian belum tersampaikan kepada masyarakat sasaran.

Menurut Dunn (2000) efisiensi (efficiency) berkenaan dengan jumlah usaha yang diperlukan untuk menghasilkan tingkat efektivitas tertentu. Efisiensi yang merupakan sinonim dari rasionalitas ekonomi, adalah merupakan hubungan antara efektivitas dan usaha. Berdasarkan hasil penelitian Asyiah (2017) dan penelitian penulis dapat disimpulkan bahwa jumlah usaha sangat dibutuhkan dalam mengoptimalkan pelaksanaan kebijakan. Jika usaha mencapai tujuan kebijakan tidak tersedia maka pelaksanaan kebijakan tidak dapat dicapai.

\section{Ketiga kecukupan}

Hasil wawancara dengan Bapak Dodi selaku masyarakat Bungus Timur pada tanggal 09 Mei 2018 dijelaskan bahwa dengan adanya pelaksanaan kebijakan tentang santunan kematian dengan memberikan uang santunan sebanyak Rp. 1 juta, itu cukup memuaskan masyarakat apalagi masyarakat miskin. Sementara Ibu Bainang selaku masyarakat Kelurahan Kuranji yang pernah mengurus dana santunan kematian pada tahun 2016 menjelaskan bahwa dana santunan kematian yang diberikan oleh Pemerintah tersebut membantu dalam penyelenggaraan jenazah.

Hasil penelitian dapat disimpulkan bahwa kecukupan dalam pelaksanaan program santunan kematian cukup memuaskan kelompok sasaran, karena dengan adanya kebijakan santunan kematian masyarakat merasa diperhatikan dan terbantu oleh Pemerintah dalam penyelenggaraan jenazah.

Berdasarkan hasil penelitian Asyiah (2017) Evaluasi Implementasi Kebijakan Pendidikan Gratis di Kabupaten Pasaman yaitu pelaksanaan pendidikan gratis di Kabupaten Pasaman sudah cukup memuaskan kebutuhan masyarakat dalam pendidikan. Menurut Dunn (2000) Kecukupan berkenaan dengan pengukuran seberapa jauh kebijakan yang ada dapat memuaskan kebutuhan masyarakat, nilai, atau kesempatan yang menimbulkan adanya masalah. 


\section{Keempat pemerataan}

Hasil wawancara dengan Bapak Hendri, selaku Kasubid Penata Usahaan Bendahara Umum Daerah pada tanggal 07 Mei 2018 dijelaskan bahwa dana santunan kematian sudah didistribusikan secara adil kepada kelompok sasaran. Selanjutnya Ibu Jasna selaku masyarakat Bungus Timur yang pernah mengurus dana santunan kematian pada tahun 2015 menjelaskan bahwa dana santunan kematian yang diterima yaitu sebanyak Rp.1 juta dari BPKAD Kota Padang.

Hasil penelitian dapat disimpulkan bahwa pemerataan dalam pelaksanaan kebijakan santunan kematian sudah didistribusikan secara adil dan merata kepada kelompok sasaran.

Berdasarkan hasil penelitian Fadhli (2014) kurang meratanya pelaksanaan program hibah POKMAS dikarenakan oleh kurang mampunya implementor dalam menyusun sendiri rencana pembiayaan pembangunan infrastruktur yang akan dilakukan dan penyusunan laporan pertanggungjawaban dari kegiatan pembangunan yang dilakukan. Menurut Dunn (2000) pemerataan dalam kebijakan publik dapat dikatakan mempunyai arti dengan keadilan yang diberikan dan diperoleh kelompok sasaran kebijakan.

Berdasarkan hasil penelitian Fadhli (2014) dan penelitian penulis dapat disimpulkan bahwa pelaksanaan kebijakan dapat berhasil apabila biaya atau manfaat suatu kebijakan didistribusikan secara merata kepada kelompok sasaran.

\section{Kelima responsivitas}

Hasil wawancara dengan Bapak Efendi selaku wartawan Pers Singgalang pada tanggal 04 Mei 2018 dijelaskan bahwa Kebijakan Walikota Padang tentang santunan kematian itu positif, tetapi masih banyak masyarakat miskin yang belum memiliki Kartu Jamkesmas atau sejenisnya, dan harus didata kembali oleh BPS demi kelancaran Kebijakan Walikota Padang tentang santunan kematian tersebut.

Selanjutnya Bapak Zikri Alhadi selaku Pengamat Sosial pada tanggal 16 Mei 2018 menjelaskan bahwa kebijakan santunan kematian tersebut bagus, membantu masyarakat yang tidak mampu untuk menyelenggarakan jenazah keluarga yang meninggal mengingat beban biaya keluarga yang ditinggalkan. Sementara itu Ibu Hasna selaku masyarakat Kelurahan Bungus Timur pada tanggal 09 Mei 2018 menjelaskan bahwa kebijakan santunan kematian ini baik dilaksanakan, karena dana santunan yang diberikan sebanyak Rp.1 juta cukup banyak, bisa terbantu dalam penyelenggaraan jenazah.

Hasil penelitian dapat disimpulkan bahwa responsivitas dalam pelaksanaan kebijakan santunan kematian semua pihak mendukung kebijakan santunan kematian dan mengharapkan pemerintah harus mendata kembali masyarakat miskin yang belum mendapatkan kartu KIS atau sejenisnya yang dibiayai oleh pemerintah dan memberikan informasi tentang kebijakan santunan kematian kepada masyarakat baik melalui semua media maupun melalui pengurus Masjid supaya kelompok sasaran bisa merasakan pelaksanaan dari kebijakan santunan kematian.

Berdasarkan penelitian Soulisa (2017) pemerintah sangat merespon secara positif kebijakan pengelolaan dana BOS di sekolah dengan fungsinya sebagai 
pengendali kebijakan yang dilakukan sehingga dapat terlaksana dengan baik dan tepat. Menurut Dunn (2000) responsivitas dapat dilihat melalui tanggapan masyarakat yang menanggapi setelah dampak kebijakan sudah mulai dapat dirasakan dalam bentuk dukungan atau penolakan.

Berdasarkan penelitian Soulisa (2017) dan penelitian penulis dapat disimpulkan bahwa suatu kebijakan dapat berhasil apabila terdapat dukungan dan harapan dari kelompok sasaran terhadap pelaksanaan kebijakan.

\section{Keenam ketepatan}

Hasil wawancara dengan Ibu Yus selaku Ibu RT 05 Kelurahan Kuranji pada tanggal 10 Mei 2018 dijelaskan bahwa Program santunan kematian ini cukup berguna bagi masyarakat untuk membeli kebutuhan dalam penyelenggaraan jenazah. Kebutuhan yang dibutuhkan pada umumnya adalah pada proses penyelenggaraan jenazah seperti membeli papan pembatas jenazah, kain kafan dan kebutuhan lainnya.

Hasil penelitian dapat disimpulkan bahwa ketepatan dalam pelaksanaan kebijakan santunan kematian sangat berguna bagi masyarakat sasaran.

Berdasarkan penelitian Fadhli (2014) Kurang tepat pelaksanaan program hibah POKMAS disebabkan oleh ketidakmampuan implementor dalam merealisasikan infrastruktur desa yang sesuai dengan kebutuhan masyarakat. Menurut Dunn (2000) ketepatan merujuk pada nilai atau harga dari tujuan kebijakan dan kuatnya pada asumsi yang melandasi tujuan-tujuan kebijakan tersebut.

Berdasarkan penelitian Fadhli (2014) dan penelitian penulis dapat disimpulkan bahwa suatu kebijakan dapat berhasil apabila pelaksanaan kebijakan bernilai dan berharga atas masalah yang sedang dihadapi oleh masyarakat sasaran.

\section{Penutup}

Berdasarkan hasil temuan dan hasil pembahasan yang telah dilakukan dapat disimpulkan bahwa evaluasi pelaksanaan Peraturan Walikota Padang Nomor 12 Tahun 2015 Tentang Santunan Kematian belum efektif. Pertama, efektivitas, pelaksanaan kebijakan santunan kematian belum efektif. Kedua, eisiensi, usaha Pemerintah dalam mengoptimalkan pelaksanaan Peraturan Walikota Padang tentang santunan kematian belum efisien. Ketiga kecukupan, kecukupan dalam pelaksanaan kebijakan santunan kematian cukup memuaskan kelompok sasaran. Keempat, pemerataan, dalam pelaksanaan kebijakan santunan kematian biaya dan manfaat sudah didistribusikan secara adil dan merata kepada kelompok sasaran. Kelima responsivitas, dalam pelaksanaan kebijakan santunan kematian, semua pihak mendukung kebijakan santunan kematian dan mengharapkan pemerintah harus mendata kembali masyarakat miskin yang belum mendapatkan Kartu Jaminan Kesehatan masyarakat atau Jaminan Kesehatan Daerah sebagai salah satu syarat untuk mendapatkan dana santunan kematian. Keenam, ketepatan, pelaksanaan kebijakan santunan kematian sangat berguna bagi masyarakat sasaran. 
Melihat dari kondisi yang ada pada hasil penelitian yang menunjukkan masih kurang terlaksananya Peraturan Walikota Nomor 12 Tahun 2015 maka penulis menyarakankan penyampaian informasi kepada kelompok sasaran dalam kebijakan oleh pemerintah harus di tingkatkan lagi sehingga dapat mengurangi distorsi dalam pelaksanaan kebijakan. Kemudian diharapkan pemerintah kembali mendata masyarakat ke Basis Data Terbapu agar masyarakat bisa mengurus dana santunan kematian.

\section{DAFTAR KEPUSTAKAAN}

\section{Buku dan Jurnal}

Anggaran, Sahya. (2012). Ilmu Administrasi Negara. Bandung: CV Pustaka Setia.

Departemen Agama RI. (2000). Al-Qur'an Karim. Surat Yunus Ayat 49 (Terjemahan). Jakarta: Departemen Agama.

Dunn,William N. (2000). Pengantar Analisa Kebijakan Publik. Yogyakarta: Gadjah Mada Press

Easton, David, Jack Dennis and Sylvia Easton. (1969). Children in the Political System: Origins of Political Legitimacy. Michigan: McGraw-Hill

Fadhli, Raja Akhmad dan Febri Yuliani. (2014). Evaluasi Program Kelompok Masyarakat.Jurnal Kebijakan Publik. Volume 5. Nomor 1. Hal 1-117.

Kementerian Kehakiman RI. (2010). Undang-Undang Nomor 36 Tahun 2009 Tentang Kesehatan. Jakarta: Kementerian Kehakiman RI.

Mulyadi, Deddy. (2015). Studi Kebijakan Publik dan Pelayanan Publik. Bandung: CV. ALFABETA.

Nugroho, Riant. (2014). Public Policy. Jakarta: PT Elex Media Komputindo.

Siti Asyiah, M. Fachri Adnan, danAdil Mubarak. (2017). Evaluasi Implementasi Kebijakan Pendidikan Gratis Di Kabupaten Pasaman.Journal of Public Sector Innovations. Volume 2. Nomor 1. Hal 1-9.

Soulisa, Nurmala Sari. (2017). Evaluasi Kebijakan Dana Bantuan Operasional Sekolah (BOS) Pada Sekolah Negeri di Kecamatan Palu Timur.Jurnal Katagolis. Volume 5. Nomor 1. Hal 91-98.

\section{Undang-Undang dan Peraturan}

Undang-Undang Nomor 36 Tahun 2009 Tentang Kesehatan

Peraturan Menteri Dalam Negeri Nomor 32 Tahun 2011 Tentang Pedoman Pemberian Hibah dan Bantuan Sosial

Peraturan Walikota Padang nomor 25 tahun 2014 tentang Santunan Kematian

Peraturan Walikota Padang nomor 29.A tahun 2014 tentang SantunanKematian

Peraturan Walikota Padang Nomor 12 Tahun 2015 Tentang Santunan Kematian 